\title{
Gyermekvállalás és szüléskimenetel sclerosis multiplexben a nemzetközi irodalom tükrében
}

\author{
Vanya Melinda dr. \\ Szegedi Tudományegyetem, Szent-Györgyi Albert Klinikai Központ, Szülészeti és Nőgyógyászati Klinika, Szeged
}

\begin{abstract}
Az utóbbi években megjelent tanulmányok egyre inkább alátámasztják, hogy bár a sclerosis multiplex már fiatal felnőtt korban manifesztálódik, ennek ellenére nem foszthatja meg a reproduktív korú nőket az anyaság csodálatos érzésétől. Sőt - az ellentmondásos nemzetközi irodalom ellenére - védőfaktor magára a betegségre, és nincs káros hatással a magzatra. Az immunmoduláns terápia alkalmazása terhesség alatt azonban egyedi elbírálást és gondos körültekintést kíván, amellyel a szakember hozzájárulhat a sclerosis multiplexben szenvedó édesanya családi boldogságához. Orv. Hetil., 2015, 156(34), 1360-1365.
\end{abstract}

Kulcsszavak: sclerosis multiplex, terhesség, vetélés, koraszülés, császármetszés, immunmoduláns terápia terhesség alatt

\section{Outcomes of childbearing and pregnancy in women with multiple sclerosis - a literature review}

In the last few years more studies indicated that although sclerosis multiplex frequently manifests in young adulthood, it should not be considered as contraindication for pregnancy in women affected with the disease. In fact, despite controversial literature data, pregnancy appears to be a protective factor to the disease without a harmful effect on the fetus. However, the use of immunomodulatory therapy during pregnancy needs a careful evaluation process and experts of this field may contribute to family happiness of the affected mother.

Keywords: multiple sclerosis, pregnancy, miscarriage, preterm birth, caesarean section, immunmodulatory treatment during pregnancy

Vanya, $M$. [Outcomes of childbearing and pregnancy in women with multiple sclerosis - a literature review]. Orv. Hetil., 2015, 156(34), 1360-1365.

(Beérkezett: 2015. május 27.; elfogadva: 2015. június 29.)

\section{Rövidítések}

IFN = interferon; $\mathrm{MR}=$ mágneses rezonancia; $\mathrm{NK}=$ natural killer sejt; PRIMS = Pregnancy in Multiple Sclerosis Study; $\mathrm{SM}=$ sclerosis multiplex; Th $=$ T-helper sejt

Az 1970-es évek előtt szinte a teljes szakirodalom eltiltotta a sclerosis multiplexes (SM) nőket a családalapítástól. Úgy tartották, hogy a gyermekvállalás fokozza a progressziót [1]. A meglévő diagnosztikai kritérium- rendszert felhasználva Schumacher és társai 1965-ben egy nagyszabású vizsgálatban megállapították, hogy a relapsusráta nem emelkedik meg számottevően a terhesség 9 hónapja alatt $[2,3]$. Számos további vizsgálat igazolta az állapotromlás jelentős csökkenését $[4,5,6,7]$, és a terhesség pozitív hatását a betegség hosszú távú lefolyására $[8,9]$. Ezek az eredmények, a hatékony immunmoduláns terápiás szerek, valamint az alacsony átörökítési kockázat megváltoztatták az addigi negatív attitüdöt, és emelkedni kezdett azoknak a nőknek a szá- 
ma, akik betegségük ellenére életet szerettek volna adni gyermeküknek/gyermekeiknek [10]. Az SM diagnózis gyakran már fiatal felnőtt korban megszületik, amikor a párok éppen a családalapítással kapcsolatos legfontosabb döntéseiket hozzák meg. Ezért számos kérdéssel fordulnak a szakemberekhez, fóként a termékenységre, fogamzásgátlásra, terhességre és szoptatásra, illetve a betegség esetleges öröklődésére vonatkozó válaszok után kutatva $[11,12]$. Természeténél fogva az SM megléte még inkább hozzátesz az élethez amúgy is hozzá tartozó bizonytalansághoz, amely nem elhanyagolható szorongást válthat ki a nőkben és családjukban.

\section{Immunológiai eltérések terhesség alatt}

Van-e specifikus immunológiai eltérés SM-ben terhesség alatt? Az elmúlt néhány év kutatásai erre a kérdésre keresték a választ. SM-ben a terhesség alatti hormonális változásoknak jótékony hatást tulajdonítanak a klinikai megjelenésre [13,14]. Számos immunológiailag aktív molekula szintje megemelkedik a várandós nók vérében, ami gyulladáscsökkentő és immunválasz-csökkentő hatással bír [15]. Az SM állatkísérletes modelljében az ösztrogén és progeszteron szuppresszív hatását figyelték meg [16]. A gyermekágyi periódusban megnövekvő kockázat, az autoimmun betegség fellángolása feltételezhetően a csökkent ösztrogénszint és a következményes immunmoduláló hatás hiányának eredménye [17]. Az orális ösztriol adagolásának pozitív hatását az SM aktivitására ismételt MR-vizsgálatokkal is kimutatták [18]. A szuppresszió mechanizmusa azon alapszik, hogy a nemi hormonok gátolják a microglia nitrit-oxid-produkcióját, ezáltal csökkentik a proinflammációs faktorok szintézisét az aktivált gliasejtben [19]. A terhességgel kapcsolatos fehérje, az alfa-foetoprotein, valamint az interleukin-10 az immunsejtek aktiválását kiváltó hatásuk miatt fontos [15], emellett ismert, hogy az interleukin-10 csökkenti a sejtes immunválaszt [20]. Az SM patogenezisében domináns Thl-mediált immunválasz szerepét feltételezik $[1,4]$. A hipotézis szerint a Thlmediált immunválasz eltolódik a Th2-sejt irányába terhesség alatt, ami változást okoz a betegség megjelenésében. A Th2-sejt citokinpredominanciája hozza létre a terhességre jellemző citokinprofilt [21]. A Thl-sejt-dominancia post partum visszatér, részben ennek köszönhető a relapsus kockázatának növekedése a szülés utáni első 3-6 hónapban. A Th1- és Th2-sejteket regulátor T-sejtek szabályozzák [22], ezért egyes kutatók szerint ezek a T-lymphocyták hozzák létre a mikrokörnyezeti toleranciát a foetomaternalis határfelületen [23]. Ezen sejtek altípusai fékezik meg az autoreaktív T-lymphocytákat autoimmun betegségekben [24]. A reguláló T-lymphocyták kapcsolata MS-ben szenvedő nők terhességével még nem tisztázott. Az NK-sejtek emelkedett számát találták SM-ben szenvedő nőkben a terhesség utolsó harmadában és a post partum periódusban [19], ami limitálja az aktivált T-sejtek számát [25]. A terhes- ségnek ebben a szakaszában mindezen immunológiai tényezôk valószínúleg szerepet játszanak az SM javulásában, pontos szerepük azonban még nem tisztázott.

Számos retrospektív [26] és prospektív [4] tanulmány kimutatta, hogy SM-ben szenvedő várandós nőkben a relapsusok száma szignifikánsan csökken a 3. trimeszterben, és jelentősen megnő a szülést követő 1 hónapban. A Pregnancy in Multiple Sclerosis Study (PRIMS) [4] volt az első nagy esetszámú, több központú felmérés, ahol 254 SM-es nő 269 terhességét követték nyomon 24 hónapig a szülést követően. Az eredmények alapján arra a következtetésre jutottak, hogy a kiindulási (terhesség előtti) relapsusrátához viszonyítva $70 \%$-kal csökken a visszaesések száma a 3. trimeszterben, és ugyancsak 70\%kal növekszik meg a post partum időszak első 3 hónapjában. Összességében tehát a relapsusráta a terhesség és szülést követő 3 hónapban megközelítően megegyezett a terhesség előttihez képest. Hasonló eredményre jutottak további 2 kisebb esetszámú vizsgálattal is [6, 27]. Egy másik felmérés enyhébb relapsustrendet igazolt terhesség alatt [5], de több és súlyosabb shubokat figyeltek meg a post partum periódusban [28]. A betegség aktivitásában bekövetkezett változásokat ismételt MR-vizsgálattal követve megállapították, hogy a terhesség második felében csökkent, míg a szülést követő első hónapban növekedett az aktív laesiók száma [29, 30].

Sajnálatos módon a primer progresszív SM-ben szenvedő nők terhességéről keveset tudunk. Erről szóló tanulmányok hiányának az lehet az oka, hogy a permanens tünetek, mint gyengeség, a hólyag- és bélproblémák megnehezítik a terhesség kihordását, ezért ilyen tünetek esetén a betegek ritkábban vállalnak terhességet. SM-ben szenvedő nőkben az urogenitalis kórképek nincsenek befolyással a szülés kimenetelére [31]. A relapsusok szempontjából magas kockázatú post partum 3 hónapban a PRIMS vizsgálatban az SM-ben szenvedő nők 28\%-a tapasztalt rosszabbodást [4]. Klinikailag prediktív (becslő) faktornak tekinthető, ha a terhesség előtti évben vagy terhesség alatt a várandós nőnek állapotrosszabbodása volt, mert ekkor nagy valószínúséggel szülés után is megjelenik a relapsus [32].

Egy kisebb esetszámú vizsgálatban a korábbi relapsusok „kórtörténete” bizonyult a legjobb indikátornak a terhesség alatt és az azt követő évben az SM klinikai lefolyásának szempontjából [33]. Az újszülött szoptatása nem befolyásolja a post partum rosszabbodás kockázatát $[3,33]$. Korábban nyilvánvalónak tünt, hogy a terhesség hatással lehet a meglévő SM-re 9 hónapnál hosszabb távon is [34]. Ezt a feltevést 125, SM-ben szenvedő nő 132 terhességének követése során cáfolták meg, ugyanis nem volt negatív befolyással a gyermekvállalás a hosszú távú prognózisra [5]. Egy kisebb esetszámú követéses vizsgálatban az asszonyok 3 éves követése során hasonló megállapításra jutottak a vizsgálók [27]. Ugyancsak ezt támasztották alá az adatok a PRIMS vizsgálatban is [4, 35]. Egy kanadai retrospektív vizsgálatban 185, SM-ben szenvedő nőnél sem találtak szignifikáns össze- 
függést a terhesség és a későbbi rokkantsági fok mértéke között [36]. A fiatalabb terhességi kor sem játszik szerepet a későbbi klinikai lefolyás alakulásában [34, 37]. Egy másik tanulmány ezt a megállapítást cáfolta, ugyanis megfigyelték, hogy a progresszív epizódok csökkennek azoknál, akik SM után szültek, összehasonlítva a korábbi eredményekkel [38]. Meg kell azonban jegyezni, hogy az eredmények értékelése meglehetősen szubjektív lehet, hiszen nagy aktivitású, gyakori relapsusokkal járó SMben szenvedő nők valószínúleg ritkábban vállalnak gyermeket.

\section{Az SM hatása a szülésre és a magzatra}

Jelenleg nem áll rendelkezésre olyan adat, amely azt bizonyítja, hogy az SM negatív hatással lenne a termékenységre, és az asszisztált reprodukciós módszerek alkalmazása sem gyakoribb SM-ben szenvedő nők körében. Nagy esetszámú tanulmányok számolnak be az SM hatásáról a terhességre, szülésre és az újszülöttre. A különböző szerzők arról számoltak be, hogy gyakoribbak a korai vetélések, amelyek aránya 23,8\% (24,9-31,8\%) [39]. Nelson és mtsai arra a következtetésre jutottak, hogy ez a kedvezőtlen kimenetel összefügg a keringő anyai antitestekkel [40].

Finkelsztejn és mtsai összefoglalójában [39] az átlagos császármetszés-gyakoriság $41,5 \%$ volt $(40,5-42,4 \%)$. Dabl és mtsai tanulmányában [41] a császármetszés gyakorisága szignifikánsan magasabb volt SM-ben szenvedó nők csoportjában, mint SM-ben nem szenvedő édesanyák esetében. E tanulmány [41] vizsgálataiban az átlagos születési súly, a terhességi kor, koraszülés és a túlhordás előfordulási gyakorisága nem tért el jelentősen az egészséges kontrollcsoportétól. Ugyanakkor Finkelsztejn és mtsai összefoglaló közleményükben utaltak arra, hogy más szerzők SM-ben szenvedő nók újszülöttjei körében gyakrabban észleltek alacsony születési súlyt és koraszülöttséget [41, 42]. Finkelsztejn és mtsai metaanalízisében a veleszületett rendellenességek ritkábban fordultak elő SM-es populációban az egészséges populációhoz viszonyítva (tartomány 0,37\%-3,3\%) [39].

Egy 198 esetet magába foglaló felmérés vizsgálói a gyermeket váró SM-es nókben az anaemia nagyobb gyakoriságát regisztrálták az SM-ben nem szenvedő kontrollcsoporthoz képest, de nem nőtt a szülési komplikációk előfordulása [37]. Néhány esetben alacsony születési súlyú magzatot, koraszülést és fejlődési rendellenességet írtak le. Egy 15 esetet számláló prospektív tanulmányban a magzati paraméterek (súly, hossz, fejkörfogat) a normális tartományban voltak [27].

\section{Aneszteziológiai megfontolások SM-ben}

Megbízható adatok állnak rendelkezésre SM-betegeken végzett aneszteziológiai és mútéti beavatkozásokról. Epiduralis analgesia alkalmazása kifejezetten előnyösnek bizonyult $[38,42]$. A spinalis anaesthesia azonban po- tenciális posztoperatív rosszabbodást válthat ki SM-ben. Ezt a nézetet más tanulmány is támogatja. Beszámoltak arról, hogy 32, SM-ben szenvedő nő körében gyakoribb volt a visszaesések aránya, ha a lokális anesztetikumok nagyobb koncentrációban voltak kimutathatók [43]. Ugyanezt találták olyan kutyák liquorában is, ahol korábban kísérletes körülmények között spinalisan végeztek eszközös vizsgálatot [42].

Az epiduralis anaesthesia nem növeli a post partum attakok számát SM-ben szenvedő anyákban [41, 42]. Ezért a császármetszés elvégzésére a lokális érzéstelenítést preferálják. A mütét indikációja megegyezik az SMben nem szenvedő nőknél követett szempontrendszerrel. A motoros tünetek, a görcs vagy csökkent izomtónus a hasi és urogenitalis szervekben, a végtagokban kihat a szülés lefolyására és időtartamára. A gyengeség az esetek többségében növeli a kimerülést, elhúzódó tágulást eredményezhet, ami a fogó használatát is szükségessé teszi $[43,44]$. Szüléskor vákuum, illetve fogómütét alkalmazása is gyakoribb SM-ben szenvedő nőkben [37], és a mentális problémák is császármetszést, illetve egyéb operatív beavatkozást indikálhatnak. A sebészi intervenciók bizonyítottan nem befolyásolják a relapsusrátát [45]. Császármetszés utáni komplikációk 21,4\%-ban fordultak elő egy norvégiai kohorszvizsgálatban, ahol 2751 volt a császármetszések száma a teljes populációban. A komplikációk előfordulása is gyakoribb volt általános anaesthesia mellett, mint regionális anaesthesia esetén [46].

\section{Az SM kezelése terhesség alatt}

A sclerosis multiplex kezelésére injekciós, illetve infúziós formulában adható gyógyszerek állnak rendelkezésre Az új, szájon át szedhető Gylenia (fingolimod) készítményt már Magyaroszágon is törzskönyvezték. Limitált adatok alapján jótékonyan hat a szekunder infertilitásra [47, 48]. A nem tervezett fogamzás immunomoduláns vagy tüneti terápia mellett is gyakori. Az interferon- $\beta$-kezelést (Avonex, Betaferon) célszerű felfüggeszteni, ha terhesség tervezett, ha már megtörtént a fogantatás és a terhességre gyanújelek utalnak, vagy ha a gyanú már megerősített megbízható teszt által. A nagyobb méretú interferon- $\alpha$ molekula nem hatol át a placentabarrieren [49]. Limitált adatok állnak rendelkezésre interferon- $\beta$ val kezelt terhes asszonyok esetén a terhesség kimenetelét tekintve, kevés esetben emelkedett vetélési kockázatot [49] és csökkent - bár statisztikailag nem szignifikáns születési súlyt figyeltek meg [50]. A legutóbbi retrospektív vizsgálatban az immunomoduláns kezelés esetleges káros hatását vizsgálták 34, SM-ben szenvedő nő terhességének teljes ideje alatt [51]. Olyan nőket követtek, akik interferonkezelés alatt álltak fogamzáskor vagy később, terhességük során, vagy akiknél felfüggesztették a kezelést. A kisszámú adat miatt azonban nem lehetett levonni biztos következtetést az interferon fejlődési rendellenességet vagy vetélést okozó esetleges hatásáról. $\mathrm{Az}$ interferon- $\beta$-val való kezelést folytatni lehet a klinikai 
rosszabbodás elkerülése érdekében, ha a várandós nő állapota feltétlenül indokolja.

A glatiramer-acetát (Copaxone) nem növeli a fejlődési rendellenességek kockázatát, ha terhesség alatt alkalmazzák [52]. Nem áll rendelkezésre olyan adat, amely szerint a glatiramer-acetát nem ajánlható terheseknek. A terápia folytatható, ha a beteg általános állapota megkívánja. A natalizumab (Tysabri) hatását kevésbé vizsgálták várandós nókben, megfelelő tapasztalat nem áll rendelkezésre, ezért kontraindikált terhesség alatt [53]. Mitoxantront sem javasolt ebben az időszakban szedni erős immunszupprimáns és teratogén hatása miatt. Utóbbi miatt nem alkalmazzák a methotrexatot és cyclophosphamidot sem. Intravénás immunoglobulin-adagolás után jelentős állapotjavulásról számoltak be [54]. Az első trimeszterben alkalmazott prednison mellett nagyobb számban fordult elő ajak- és szájpadhasadék [54, 55]. A terhesség alatt akut relapsus kezelésére methylprednisolon vagy prednison alkalmazható a 2 . és 3. trimeszterben. Nem várandós nőkben a rövid időtartamú, nagy dózisú methylprednisolon-lökésterápiát javasolják [54]. A gyengeség, a vizeletürítési és emésztőrendszeri funkciózavar, spasticitas, járási nehézség és fájdalom jelentősen rontja a terhes általános állapotát. Ezekre a tünetekre használatos szerek nagy része nem alkalmazható terhességben [56].

\section{SM és gyermekágy}

A szoptatás nem befolyásolja a post partum attakok gyakoriságát és számát $[53,57]$. Bátorítani kell az SM-ben szenvedő nőt a szoptatásra, elsősorban az újszülött számára nélkülözhetetlen tápanyagok és ellenanyagok miatt. Több központ bevonásával készült tanulmányban post partum intravénás immunglobulin adagolását követően 163, SM-ben szenvedő nőben az anyatejes táplálás felmérésekor a nők 85\%-a 3 hónapig vagy tovább szoptatott [58].

A szülés utáni visszaesések számától és az általános rokkantsági foktól függ, hogy az SM-ben szenvedő nók anyai feladataiknak mennyire tudnak eleget tenni. Immunmoduláns terápiás szerek használata ebben az időszakban attól függ, hogy ezek milyen mértékben jutnak az anyatejbe és károsítják-e az újszülöttet. Közepes dózisú methylprednisolon jótékony hatással van a post partum relapsusokra [59].

Nagy dózisú kortikoszteroidkezelés mellett a szer kiválasztódik az anyatejjel és az újszülöttben növekedési elmaradást, csökkent csontfejlődést okoz és befolyásolja az endogén hormontermelést. Az interferon- $\alpha$ nem választódik ki az anyatejbe klinikailag releváns mennyiségben [60]. Nem ismert azonban, hogy az interferon- $\beta$ egy része átjut-e az anyatejbe és felszívódik-e a csecsemőben, ezért nem javallt szoptatás idején. A glatirameracetátról nem ismert, hogy szoptatással a csecsemőbe jutna. Neurológusok körében végzett felmérés szerint a megkérdezettek 86\%-a nem írt fel immunomoduláns ké- szítményt a gyermekágyi szakban, vagy ha igen, akkor az esetek többségében a glatiramer-acetátot (Copaxone) [61].

A mitoxantron és a cyclophosphamid nagy mennyiségben átjut az anyatejbe, ezért alkalmazásuk nem javasolt. Ha az édesanya feltétlenül folytatni szeretné a szoptatást, akkor az intravénás immunglobulin a leghatásosabb a relapsus csökkentésére, és a csecsemőre sincs káros hatással $[52,57]$.

A kóros fáradékonyság nagyon kifejezett lehet SMben szenvedő nőben, ezért még inkább elötérbe kerül a családsegítő szerepe. Az egyéni feladatok ellátása a háztartásban, az újszülött anyatejjel való táplálása, az anyagyermek kapcsolat kialakítása neurológiai betegség nélkül sem könnyű feladat, azonban a tudat, hogy egészséges gyermeket hozott a világra, erôt adhat az SM-ben szenvedő édesanyának nemcsak ezen feladatok ellátására, hanem a betegséggel való megküzdéshez is.

\section{Következtetések}

Az SM-ben szenvedő édesanya és gyermekének egészsége érdekében az egészségügyi személyzet (neurológusok, szülész-nőgyógyászok és neonatológusok) szoros kooperációja elengedhetetlen a fogamzás időpontjától egészen a post partum időszakig.

Anyagi támogatás: A közlemény megírása anyagi támogatásban nem részesült.

A cikk végleges változatát a szerző elolvasta és jóváhagyta.

Érdekeltségek: A szerzőnek nincsenek érdekeltségei.

\section{Irodalom}

[1] Damek, D. M., Shuster, E. A.: Pregnancy and multiple sclerosis. Mayo Clin. Proc., 1997, 72(10), 977-989.

[2] Korn-Lubetzki, I., Kahana, E., Cooper, G., et al.: Activity of multiple sclerosis during pregnancy and puerperium. Ann. Neurol., $1984,16(2), 229-231$.

[3] Nelson, L. M., Franklin, G. M., Jones, M. C.: Risk of multiple sclerosis exacerbation during pregnancy and breast-feeding. JAMA, 1988, 259(23), 3441-3443.

[4] Confavreux, C., Hutchinson, M., Hours, M. M., et al.: Rate of pregnancy-related relapse in multiple sclerosis. Pregnancy in Multiple Sclerosis Group. N. Engl. J. Med., 1988, 339(5), 285291.

[5] Roullet, E., Verdier-Taillefer, M. H., Amarenco, P., et al.: Pregnancy and multiple sclerosis: a longitudinal study of 125 remittent patients. J. Neurol. Neurosurg. Psychiatry, 1993, 56(10), $1062-1065$.

[6] Sadovnick, A. D., Eisen, K., Hashimoto, S. A., et al.: Pregnancy and multiple sclerosis. A prospective study. Arch. Neurol., 1994, 51(11), 1120-1124.

[7] Ebers, G. C., Sadovnick, A. D., Risch, N. J., et al.: A genetic basis for familial aggregation in multiple sclerosis. Canadian Collaborative Study Group. Nature, 1995, 377(6545), 150-151. 
[8] Poser, S., Poser, W.: Multiple sclerosis and gestation. Neurology, 1983, 33(11), 1422-1427.

[9] Ferrero, S., Pretta, S., Ragni, N.: Multiple sclerosis: management issues during pregnancy. Eur. J. Obstet. Gynecol. Reprod. Biol., 2004, 115(1), 3-9.

[10] Ferrero, S., Esposito, F., Pretta, S., et al.: Fetal risks related to the treatment of multiple sclerosis during pregnancy and breastfeeding. Expert Rev. Neurother., 2006, 6(12), 1823-1831.

[11] Van Wijk, I. J., de Hoon, A. C., Jurbawan, R., et al.: Detection of apoptotic fetal cells in plasma of pregnant women. Clin. Chem. 2000, 46(5), 729-731.

[12] Airas, L., Saraste, M., Rinta, S., et al.: Immunoregulatory factors in multiple sclerosis patients during and after pregnancy: relevance of natural killer cells. Clin. Exp. Immunol., 2007, 151(12), 235-243.

[13] Ostensen, M., Villiger, P. M.: The remission of rheumatoid arthritis during pregnancy. Semin. Immunopathol., 2007, 29(2), 185191.

[14] Voskubl, R. R.: Hormone-based therapies in MS. Int. MS J., 2003, 10(2), 60-66.

[15] Houtchens, M. K.: Pregnancy and multiple sclerosis. Semin. Neurol., 2007, 27(5), 434-441.

[16] Trooster, W.J., Teelken, A. W., Kampinga, J., et al.: Suppression of acute experimental allergic encephalomyelitis by the synthetic sex hormone 17-alpha-ethinylestradiol: an immunological study in the Lewis rat. Int. Arch. Allergy Immunol., 1993, 102(2), 133140 .

[17] Jansson, L., Holmdahl, R.: Estrogen-mediated immunosuppression in autoimmune diseases. Inflamm. Res., 1998, 47(7), 290301

[18] Sicotte, N. L., Liva, S. M., Klutch, R., et al.: Treatment of multiple sclerosis with the pregnancy hormone estriol. Ann. Neurol., 2002, 52(4), 421-428.

[19] Drew, P. D., Chavis, J. A.: Female sex steroids: effects upon microglial cell activation. J. Neuroimmunol., 2000, 111(1-2), 7785.

[20] Kieseier, B. C., Benamor, M.: Pregnancy outcomes following maternal and paternal exposure to teriflunomide during treatment for relapsing-remitting multiple sclerosis. Neurol. Ther., 2014 $3(2), 133-138$

[21] Al-Shammri, S., Rawoot, P., Azizieh, F., et al.: Thl/Th2 cytokine patterns and clinical profiles during and after pregnancy in women with multiple sclerosis. J. Neurol. Sci., 2004, 222(1-2), 2127.

[22] Van den Broek, H. H., Damoiseaux, J. G., De Baets, M. H., et al.: The influence of sex hormones on cytokines in multiple sclerosis and experimental autoimmune encephalomyelitis: a review. Mult. Scler., 2005, 11(3), 349-359.

[23] Zenclussen, A. C., Schumacher, A., Zensclussen, M. L., et al.: Immunology of pregnancy: cellular mechanisms allowing fetal survival within the maternal uterus. Expert Rev. Mol. Med., 2007, 9(10), 1-14.

[24] Takahashi, T., Sakaguchi, S.: The role of regulatory T cells in controlling immunologic self-tolerance. Int. Rev. Cytol., 2003 , $225,1-32$

[25] Bielekova, B., Catalfamo, M., Reichert-Scrivner, S., et al.: Regulatory CD56 (bright) natural killer cells mediate immunomodulatory effects of IL-2 $\alpha$-targeted therapy (daclizumab) in multiple sclerosis. Proc. Natl. Acad. Sci. U.S.A., 2006, 103(15), $5941-$ 5946.

[26] Salemi, G., Callari, G., Gammino, M., et al.: The relapse rate of multiple sclerosis changes during pregnancy: a cohort study. Acta Neurol. Scand., 2004, 110(1), 23-26.

[27] Worthington, J., Jones, R., Crawford, M., et al.: Pregnancy and multiple sclerosis - a 3-year prospective study. J. Neurol., 1994, 241(4), 228-233.

[28] Paavilainen, T., Kurki, T., Parkkola, R., et al.: Magnetic resonance imaging of the brain used to detect early postpartum acti- vation of multiple sclerosis. Eur. J. Neurol., 2007, 14(11), 12161221.

[29] Van Walderveen, M. A., Tas, M. W., Barkhof, F., et al.: Magnetic resonance evaluation of disease activity during pregnancy in multiple sclerosis. Neurology, 1993, 44(2), 327-329.

[30] Durufle, A., Petrilli, S., Nicolas, B., et al.: Effects of pregnancy and child birth on urinary symptoms and urodynamics in women with multiple sclerosis. Int. Urogynecol. J. Pelvic Floor Dysfunct., 2006, 17(4), 352-355.

[31] Vukusic, S., Hutchinson, M., Hours, M., et al.: Pregnancy and multiple sclerosis (the PRIMS study): clinical predictors of postpartum relapse. Brain, 2004, 127(6), 1353-1360.

[32] Achiron, A., Kischner, I., Doley, M., et al.: Effect of intravenous immunoglobulin treatment on pregnancy and postpartum-related relapses in multiple sclerosis. J. Neurol., 2004, 251(9), 11331137.

[33] Bennett, K. A.: Pregnancy and multiple sclerosis. Clin. Obstet. Gynecol., 2005, 48(1), 38-47.

[34] Weinshenker, B. G., Hader, W., Carrierre, W., et al.: The influence of pregnancy on disability from multiple sclerosis: a populationbased study in Middlesex County, Ontario. Neurology, 1989, $39(11), 1438-1440$

[35] Thompson, D. S., Nelson, L. M., Burns, A., et al.: The effects of pregnancy in multiple sclerosis: a retrospective study. Neurology, 1986, 36(8), 1097-1099.

[36] Runmarker, B., Andersen, O.: Pregnancy is associated with a lower risk of onset and a better prognosis in multiple sclerosis. Brain, 1995, 118(1), 253-261.

[37] Mueller, B. A., Zhang, J., Critchlow, C. W.: Birth outcomes and need for hospitalization after delivery among women with multiple sclerosis. Am. J. Obstet. Gynecol., 2002, 186(3), 446-452.

[38] Bader, A. M., Hunt, C. O., Datta, S., et al.: Anesthesia for the obstetric patient with multiple sclerosis. J. Clin. Anesth., 1988, l(1), 21-24.

[39] Finkelsztejn, A., Brooks, J. B., Paschoal, F. M. Jr., et al.: What can we really tell women with multiple sclerosis regarding pregnancy? A systematic review and meta-analysis of the literature. BJOG, 2011, 118(7), 790-797.

[40] Nelson, J. L.: Maternal-fetal immunology and autoimmune disease. Is some autoimmune disease auto-alloimmune or allo-autoimmune? Arthritis Rheum., 1996, 39(2), 191-194.

[41] Dabl, J., Mybr, K. M., Daltveit, A. K., et al.: Pregnancy, delivery and birth outcome in different stages of maternal multiple sclerosis. J. Neurol., 2008, 255(5), 623-627.

[42] Cohen, E. N.: Distribution of local anesthetic agents in the neuraxis of the dog. Anesthesiology, 1968, 29(5), 1002-1005.

[43] Davis, R. K., Maslow, A. S.: Multiple sclerosis in pregnancy: a review. Obstet. Gynecol. Surv., 1992, 47(5), 290-296.

[44] Sibley, W. A., Bamford, C. E.,Clark, K., et al.: A prospective study of physical trauma and multiple sclerosis. J. Neurol. Neurosurg. Psychiatry, 1991, 54(7), 584-589.

[45] Häger, R. M., Daltveit, A. K., Hofoss, D., et al.: Complications of cesarean deliveries: rates and risk factors. Am. J. Obstet. Gynecol., 2004, 190(2), 428-434.

[46] Pons, J. C., Lebon, P., Frydman, R., et al.: Pharmacokinetics of interferon-alpha in pregnant women and fetoplacental passage. Fetal. Diagn. Ther., 1995, 10(1), 7-10.

[47] Inshasi, J., Almadani, A., Alrukn, S., et al.: Fingolimod (Gilenya) may improve the chances of conception in women with multiple sclerosis (MS) associated with secondary infertility. Mult. Scler. Relat. Disord., 2014, 3(6), 749-750.

[48] De Giglio, L., Gasperini, C., Tortorella, C., et al.: Natalizumab discontinuation and disease restart in pregnancy: a case series. Acta Neurol. Scand., 2015, 131(5), 336-340.

[49] Sandberg-Wollheim, M., Frank, D., Goodwin, T. M., et al.: Pregnancy outcomes during treatment with interferon beta-la in patients with multiple sclerosis. Neurology, 2005, 65(6), 802-806. 
[50] Boskovic, R., Wide, R., Wolpin, J., et al.: The reproductive effects of beta interferon therapy in pregnancy: a longitudinal cohort. Neurology, 2005, 65(6), 807-811.

[51] De Las Heras, V., De Andrés, C., Téllez, N., et al.: Pregnancy in multiple sclerosis patients treated with immunomodulators prior to or during part of the pregnancy: a descriptive study in the Spanish population. Mult. Scler., 2007, 13(8), 981-984.

[52] Tremlett, H. L., Oger, J.: Ten years of adverse drug reaction reports for the multiple sclerosis immunomodulatory therapies: a Canadian perspective. Mult. Scler., 2008, 14(1), 94-105.

[53] Hale, T. W.: Medications and mothers' milk. 12th edn. Hale Publishing, Amarillo, 2006

[54] Park-Wyllie, L., Mazzotta, P., Pastuszak, A., et al.: Birth defects after maternal exposure to corticosteroids: prospective cohort study and meta-analysis of epidemiological studies. Teratology, 2000, 62(6), 385-392

[55] Schwendimann, R. N., Alekseeva, N.: Gender issues in multiple sclerosis. Int. Rev. Neurobiol., 2007, 79, 377-392.

[56] Weber-Schoendorfer, C., Shaefer, C.: Multiple sclerosis, immunmodulators, and pregnancy outcome: a prospective observational study. Mult. Scler., 2009, 15(9), 1037-1042.
[57] Kumar, A. R., Hale, T. W., Mock, R. E.: Transfer of interferon alfa into human breast milk. J. Hum. Lact., 2000, 16(3), 226228.

[58] Coyle, P. K., Christie, S., Fodor, P., et al.: Multiple sclerosis gender issues: clinical practices of women neurologists. Mult. Scler., $2004,10(5), 582-588$.

[59] Ferrero, S., Pretta, S., Ragni, N.: Multiple sclerosis: management issues during pregnancy. Eur. J. Obstet. Gynecol. Reprod. Biol., 2004, 115(1), 3-9.

[60] Ramagopalan, S. V., Herrera, B. M., Valdar, W., et al.: No effect of birth weight on the risk of multiple sclerosis. A populationbased study Neuroepidemiology, 2008, 31(3), 181-184.

[61] Patti, F., Cavallaro, T., Lo Fermo, S., et al.: Is in utero early-exposure to interferon beta risk factor for pregnancy outcomes in multiple sclerosis? J. Neurol., 2008, 255(8), 1250-1253.

(Vanya Melinda dr., Szeged, Semmelweis u. 1., 6725 e-mail: vanya.melinda@med.u-szeged.hu vmelinda74@gmail.com)

\title{
PÁLYÁZAT
}

\author{
A Tatabányai Szent Borbála Kórház Főigazgatója \\ pályázatot hirdet \\ fül-orr-gégész szakorvos \\ részére.
}

Az álláshely közalkalmazotti és egyéb jogviszonyban is betölthetö.

Továbbá várjuk fül-orr-gégész szakorvosok jelentkezését ügyeleti feladatok ellátására.

Pályázati feltétel: fül-orr-gégész szakvizsga.

Bérezés: megegyezés szerint.

Feladata: a munkaköri leírásban foglaltak alapján, szakirányú képesítésének megfelelő szakorvosi tevékenység végzése.

\section{A jelentkezéshez csatolandók:}

- végzettséget igazoló okmányok másolata

- müködési nyilvántartás érvényesitéséről szóló határozat

- kamarai tagság igazolása

- 3 hónapnál nem régebbi hatósági bizonyítvány (erkölcsi)

- részletes szakmai önéletrajz.

Az állás a pályázat elbirálását követően azonnal betölthető.

A pályázati anyagot az Orvos igazgatói Titkárságra (a fentiekben megjelölt másolatokkal, önéletrajzzal együtt) kérjük benyújtani.

(2800 Tatabánya, Dózsa György út 77.)

Telefon: 06-34/515-470

A boritékra kérjük írják rá: „Pályázat fül-orr-gégész szakorvosi álláshelyre”. 